\title{
PENGARUH PEMUPUKAN NITROGEN DAN TINGKAT NAUNGAN TERHADAP KANDUNGAN BAHAN KERING, SERAT KASAR DAN ABU RUMPUT Brachiaria humidicola
}

\author{
Novita Salim*, S.D. Anis, F. Dompas, W.B. Kaunang \\ Fakultas Peternakan Universitas Sam Ratulangi Manado, 95115
}

\begin{abstract}
ABSTRAK
Penelitian ini bertujuan mengkaji pengaruh level naungan dan pengaruh pemupukan nitrogen terhadap hasil bahan kering, serat kasar dan abu. Perlakuan yang diuji terdiri dari empat level pupuk nitrogen dalam bentuk pupuk urea : $\mathrm{P}_{1}=0 \mathrm{~kg} / \mathrm{Ha}, \mathrm{P}_{2}=$ $50 \mathrm{~kg} / \mathrm{Ha}, \mathrm{P}_{3}=100 \mathrm{~kg} / \mathrm{Ha}, \mathrm{P}_{4}=150 \mathrm{~kg} / \mathrm{Ha}$, dan tiga level naungan : $\mathrm{N}_{1}=0 \%, \mathrm{~N}_{2}=40 \%$, dan $\mathrm{N}_{3}=70 \%$. Perlakuan diatur secara faktorial pada Rancangan Dasar Acak Kelompok (RAK). Data dianalisis keragaman dengan Minitab Versi 11, dan perbedaan perlakuan diuji dengan Tukey Simulteneous Test. Uji Tukey Simulteneous Test menunjukan bahwa interaksi $\mathrm{N}_{1} \mathrm{P}_{4}$ nyata lebih tinggi dibandingkan interaksi lainnya. Analisis keragaman menunjukan bahwa pengaruh pemupukan dan naungan menunjukan perbedaan yang tidak nyata terhadap bahan kering, serat kasar, dan abu, tetapi interaksi dari kedua faktor perlakuan tersebut memberikan pengaruh yang berbeda nyata terhadap serat kasar sedangkan pada bahan kering dan abu tidak berbeda nyata. Dari hasil penelitian ini dapat disimpulkan bahwa pada kondisi lingkungan tanpa naungan peningkatan level pengaruh nitrogen sampai $150 \mathrm{~kg}$ urea/Ha meningkatkan kandungan serat kasar.
\end{abstract}

Kata kunci: nitrogen, naungan, bahan kering, serat kasar, abu, humidicola

*Korespondensi (corresponding author):

Email: Novitasalim32@yahoo.com

\section{ABSTRACT}

THE EFFECTS OF NITROGEN FERTILIZER AND SHADING LEVELS ON DRY MATTER, CRUDE FIBER AND ASH CONTENT OF Brachiaria humidicola. The aim of this experiment was to determine the effects of fertilizer different level of shading and nitrogen on the crude fiber, dry matter and ash content. The treatments consisted of four levels of nitrogen in from of urea fertilizer : $\mathrm{P}_{1}=0 \mathrm{~kg} / \mathrm{Ha}, \mathrm{P}_{2}=50 \mathrm{~kg} / \mathrm{Ha}, \mathrm{P}_{3}$ $=100 \mathrm{~kg} / \mathrm{Ha}, \mathrm{P}_{4}=150 \mathrm{~kg} / \mathrm{Ha}$, and of three levels of shading : $\mathrm{N}_{1}=0 \%, \mathrm{~N}_{2}=40 \%$, and $\mathrm{N}_{3}$ $=70 \%$. Treatments whe arranged in factorial based on randomized block design (RBD). Data were analysis using Minitab Version 11, and followed by Tukey Simulteneous Test. The highest crude fiber content was in $\mathrm{N}_{1} \mathrm{P}_{4}$ coupared to other interactions. The result showed that the effect of Nitrogen fertilizer and shading were no significant on dry matter, ash and crude fiber content of B. humidicola however, the interaction of the two factor were significant only on crude fiber content. It can be concluded that the best condition was on $0 \%$ without with $150 \mathrm{~kg}$ Nitrogen fertilizer /Ha.

Keyword : nitrogen, shading, dry matter, fiber, ash, humidicola

\section{PENDAHULUAN}

\section{Rumput Brachiaria humidicola}

(Rendle) Schweick berasal dari daerah

Afrika tropis dan menyebar secara alamiah. Rumput B. Humidicola 
merupakan hijauan palatabel yang dapat digunakan sebagai rumput potongan dan rumput penggembalaan. Rumput ini mempunyai kemampuan menekan pertumbuhan gulma, adaptif terhadap pengairan kurang baik, toleran terhadap penggembalaan berat, dan tidak begitu membutuhkan kesuburan tanah yang bagus sehingga mempunyai peranan yang cukup besar bagi pengembangan dan penyediaan hijauan di daerah tropik. Rumput ini juga memiliki kemampuan menutup tanah yang baik karena adanya stolon dan rizoma, sehingga dikenal sebagai tanaman penutup tanah dan pencegah erosi, sekaligus sumber pakan ternak ruminan (Skerman and Riveros, 1990). Rumput ini bisa tumbuh pada beragam jenis tanah mulai dari tanah sangat asam tidak subur $(\mathrm{pH}$ 3,5), tanah dengan aluminium tinggi, tanah liat berat, sampai tanah pasir berbatu dengan $\mathrm{pH}$ tinggi, kebutuhan $\mathrm{Ca}$ rendah, dan tahan terhadap tanah berpengairan buruk. Tumbuh terbaik pada sinar matahari penuh tetapi daya tahan naungan sedang (misalnya di bawah naungan perkebunan kelapa yang sudah tua), dan tumbuh paling baik di bawah kondisi penggembalaan sedang sampai berat karena kemampuan tumbuh stolon yang sangat kuat, memberi penutup tanah meski di bawah kondisi penggembalaan berat (Anis dan Kaligis, 2012; Feng et al., 2008). Penggunaan unsur nitrogen dengan dosis yang tepat dan berada pada kondisi lingkungan dan manajemen yang baik akan meningkatkan produksi daun dan anakan (Bona and Montteiro, 2010; Schmit et al., 2013).

Cahaya matahari penting dan diperlukan dalam proses fotosintesis. Pertumbuhan tanaman akan meningkat seiring dengan meningkat seiring dengan meningkatnya intensitas cahaya sampai titik kejenuhan cahaya tertentu. Laju fotosintesis berhubungan dengan ketersediaan air dan karbon dioksida, serta energi matahari. Kondisi kekurangan cahaya berakibat terganggunya metabolisme, sehingga menyebabkan menurunnya laju fotosintesis dan sistem karbohidrat (Grivnes, 1988; Ginting and Tarigan, 2007). Energi cahaya bertanggung jawab terhadap kegiatan fotosintesis dan sejumlah pengikat $\mathrm{N}$ melalui reaksi kimia. Intensitas cahaya yang optimum juga berbeda menurut jenis tanaman. Berdasarkan latar belakang diatas maka penelitian ini dilaksanakan untuk mengetahui dan mempelajari pengaruh pemupukan nitrogen dan tingkat naungan terhadap kandungan bahan kering, serat kasar dan abu rumput Brachiaria humidicola.

\section{MATERI DAN METODE PENELITIAN}


Penelitian ini telah dilaksanakan di Desa Buha pada Balai Pengkajian dan Penerapan Teknologi Pertanian (BPPTP) selama 2 bulan. Bahan penelitian yang digunakan berupa anakan rumput Brachiaria humidicola yang diambil dari kebun percobaan Fakultas Peternakan UNSRAT, pupuk urea, pupuk TSP dan KCL. Peralatan yang digunakan adalah paranet dengan tingkat naungan $40 \%$ dan $70 \%$ thermometer suhu maximum dan minimum, sprayer, timbangan, serta peralatan untuk keperluanpanen dan penanganan sampel. Perlakuan yang diuji dalam penelitian ini adalah tingkat penggunaan pupuk nitrogen (Faktor A) dengan dosis pupuk urea $\mathrm{P}_{1}=0 \mathrm{~kg} / \mathrm{Ha}, \mathrm{P}_{2}$ $=50 \mathrm{~kg} / \mathrm{Ha}, \mathrm{P}_{3}=100 \mathrm{~kg} / \mathrm{Ha}$, dan $\mathrm{P}_{4}=150$ $\mathrm{kg} / \mathrm{Ha}$, sedangkan Faktor B adalah tingkat naungan $\mathrm{N}_{1}=0 \%, \mathrm{~N}_{2}=40 \%$ dan $\mathrm{N}_{3}=$ 70\%. Perlakuan di tempatkan secara faktorial menggunakan rancangan dasar acak kelompok (RAK) dengan dua ulangan. Pengelompokan didasarkan pada perbedaan jenis vegetasi yang ada pada lahan tersebut sebelum diolah menjadi petak percobaan. Lahan yang digunakan dibersihkan dari gulma dan untuk dapatkan media tumbuh yang siap tanam, tanah dibongkar dan dihaluskan dengan menggunakan cangkul sehingga didapatkan partikel tanah yang lebih kecil kemudian diratakan. Lahan dibiarkan selama tiga minggu sampai semua gulma tumbuh kembali dan dikontrol dengan herbisida Roundup. Selanjutnya dibuat petakan 3 x 3 meter. Anakan $B$. humidicola ditanam di setiap petak dengan jarak tanam $30 \mathrm{~cm}$ x $30 \mathrm{~cm}$, dibiarkan selama 30 hari kemudian dilakukan trimming untuk dapatkan pertumbuhan yang seragam. Pupuk dasar TSP dan KCL diberikan bersamaan pada saat pengolahan lahan dengan dosis masing-masing 75 $\mathrm{kg} / \mathrm{Ha}$. Sedangkan pupuk urea sebagai perlakuan diberikan pada tiap petak sesuai dosis perlakuan yang diuji pada umur pertumbuhan kembali satu minggu setelah trimming. Paranet dipasang menutupi setiap petak sesuai perlakuan dengan tingkat naungan $40 \%$ dan $70 \%$ setelah trimming. Untuk menyangga paranet digunakan kayu dan bambu dengan ketinggian naungan satu meter dari permukaan tanah. Panen dilakukan pada umur 30 hari setelah trimming. Panen dilakukan dengan cara memotong rumput B. humidicola setinggi $10 \mathrm{~cm}$ diatas permukaan tanah. Pengambilan sampel dilakukan dengan menggunakan bingkai bujur sangkar berukuran 100 x $50 \mathrm{~cm}$ sebanyak 2 cuplikan per petak kemudian campur merata dan diambil sampel sebanyak $2 \mathrm{~kg}$ segar. Setelah sampel dapatkan berat kering tetap, 
digiling sampai halus, kemudian dimasukan kembali kedalam oven pada suhu $105{ }^{0} \mathrm{C}$ selama 24 jam untuk mendapatkan kandungan bahan kering. Selanjutnya kandungan serat kasar dilakukan dengan menggunakan metode analisis Van Soest dilaksanakan di Laboratorium Lahan Tanah Fakultas Peternakan UNSRAT.

\section{Variabel penelitian}

Bahan kering. sampel dikeringkan dengan sinar matahari selama satu minggu kemudian sampel dimasukan kedalam oven dengan suhu panas $105{ }^{0} \mathrm{C}$ sampai sampel benar-benar kering untuk mendapatkan data produksi bahan kering. Lalu sampel ditimbang dan diberi kode sampel.

Kandungan abu. Setelah sampel sudah mendapatkan berat kering tetap, sampel digiling sampai halus kemudian dimasukan kedalam oven untuk mengurangi kadar air. Kemudian sampel dimasukan kedalam crustsibel lalu ditimbang untuk mendapatkan berat awal. Sampel yang sudah ditimbang dimasukan ke dalam tanur dengan suhu panas $400{ }^{\circ} \mathrm{C}$ untuk menghasilkan abu.

Kandungan serat kasar. Untuk mengetahui kandungan serat kasar sampel dianalisis di Laboratorium dengan menggunakan menggunakan metode analisis van soest.

\section{HASIL DAN PEMBAHASAN}

\section{Kandungan Serat Kasar}

Hasil analisi keragaman menunjukan bahwa interaksi perlakuan berpengaruh nyata terhadap kandungan serat kasar B. humidicola. Sebagaimana terlihat pada Tabel 1 .

Tabel 1. Pengaruh Interaksi Perlakuan Terhadap Kandungan Serat Kasar

\begin{tabular}{lcccc}
\hline & \multicolumn{4}{c}{ Pupuk } \\
\cline { 2 - 5 } Naungan & $\mathrm{P}_{1}$ & $\mathrm{P}_{2}$ & $\mathrm{P}_{3}$ & $\mathrm{P}_{4}$ \\
\hline $\mathrm{N}_{1}$ & $36.1883^{\mathrm{b}}$ & $36.3545^{\mathrm{b}}$ & $37.0272^{\mathrm{b}}$ & $38.8109^{\mathrm{a}}$ \\
$\mathrm{N}_{2}$ & $30.1297^{\mathrm{c}}$ & $34.5438^{\mathrm{c}}$ & $33.2677^{\mathrm{c}}$ & $32.7886^{\mathrm{c}}$ \\
$\mathrm{N}_{3}$ & $35.2520^{\mathrm{c}}$ & $34.9028^{\mathrm{c}}$ & $33.3185^{\mathrm{c}}$ & $35.4643^{\mathrm{c}}$ \\
\hline
\end{tabular}

Ket : superscript berbeda pada lajur yang sama berbeda nyata $(\mathrm{P}<0,05)$ 
Tabel 2. Hasil Bahan Kering dan Abu

\begin{tabular}{llllcccc}
\hline \multirow{3}{*}{ Variabel } & \multicolumn{9}{c}{ Naungan } & \multicolumn{4}{c}{ Pemupukan } \\
\cline { 2 - 8 } & \multicolumn{1}{c}{$\mathrm{N}_{1}$} & $\mathrm{~N}_{3}$ & $\mathrm{P}_{1}$ & $\mathrm{P}_{2}$ & $\mathrm{P}_{3}$ & $\mathrm{P}_{4}$ \\
Bahan Kering(gr/ptk) & 174.16 & 141.94 & 129.45 & 140.31 & 140.49 & 136.6 & 135.94 \\
Abu (\%) & 18.55 & 20.46 & 18.52 & 20.09 & 18.29 & 20.07 & 18.25 \\
\hline
\end{tabular}

Ket : tidak ada perbedaan yang nyata $(\mathrm{P}>0,05)$

Uji lanjut dengan Tukey Test menunjukan interaksi perlakuan $\mathrm{N}_{1} \mathrm{P}_{4}$ menghasilkan kandungan serat kasar $38,81 \%$ nyata lebih tinggi $(\mathrm{P}<0,05)$ dibandingkan dengan interaksi perlakuan lainnya. Secara umum diperoleh bahwa kandungan serat kasar nyata lebih tinggi pada interaksi antara perlakuan pemupukan nitrogen dengan perlakuan tanpa Naungan $\left(\mathrm{N}_{1}\right)$, dibandingkan dengan interaksi antara perlakuan nitrogen dengan perlakuan Naungan $40 \% \quad\left(\mathrm{~N}_{2}\right)$ dan Naungan $70 \% \quad\left(\mathrm{~N}_{3}\right)$. Hal ini mungkin disebabkan karena pada kondisi tanpa naungan fotosintesis berjalan lebih baik yang berpengaruh positif pada pertumbuhan tanaman (Baharsjah dan Darmawan, 1983 ; Fisher et al., 2007).

\section{Hasil Bahan Kering dan Abu}

Perlakuan dalam penelitian ini tidak membarikan pengaruh tidak nyata memberikan pengaruh tidak nyata $(\mathrm{P}>0,05)$ terhadap hasil bahan kering dan abu rumput $B$. humidicola, sebagaimana tertera pada Tabel 2 .
Baik level naungan maupun level pupuk nitrogen tidak berpengaruh nyata $(\mathrm{P}>0,05)$ terhadap kadar abu. Kendatipun tidak berbeda secara statistik, namun terlihat bahwa pada perlakuan tanpa naungan $\left(\mathrm{N}_{1}\right)$ atau cahaya matahari penuh tetap memberikan hasil bahan kering lebih tinggi sebanyak 174,16 gr dibandingkan dengan naungan $40 \%$ hasil bahan kering turun menjadi 141,94 dan pada naungan $70 \%$ turun lebih rendah menjadi 129,45 gr. Selanjutnya level pemupukan $\mathrm{N}$ tidak berpengaruh nyata pada hasil bahan kering.

\section{KESIMPULAN}

Dari hasil penelitian ini dapat disimpulkan bahwa faktor naungan $\mathrm{N}_{1} \mathrm{P}_{4}$ berpengaruh dominan terhadap turunnya kadar serat kasar walaupun diberi pupuk nitrogen tetapi kandungan serat kasar pada rumput $B$. humidicola lebih dominan dipengaruhi oleh faktor naungan. Faktor naungan berinteraksi menurunkan hasil bahan kering rumput B. humidicola. 


\section{DAFTAR PUSTAKA}

Anis, S.D dan D.A Kaligis . 2012. Karakteristik dan pola tumbuh Brachiaria cv Tully di areal Tegakan kelapa. Prosiding Seminar Nasional Pembangunan Peternakan berkelanjutan. UNPAD. Jatinangor.

Bona, D and F.A. Montteiro. 2010. The development and production of leaf and tillers by Marundu Palisadegrass ferthized with nitrogen and sulphur. Tropical Grassiand 44: 192-201.

Baharsjah, J.S dan J. Darmawan. 1983. Dasardasar Fisiologi-Tanaman. Penerbit: Suryahdu. Semarang

Fisher, M.J., S.P. Braz, R.S.M do Santos, Urquiaga, B.J.R. Alves, R.M. Boddey. 2007. Another dimension to grazing systems: soil carbon. Trop. Grasal. 41 : 65-83.

Feng, Y.L., Gai-Lan Fu and Yu-Long Zheng. 2008. Specific leaf area related to the differences in leaf construction cost, photosyuthesis, nitrogen allocation and use efficiency between invasive and invasive alien congeners. Planta 228 : 390.

Grivnes, T.J. 1988. Adaptation to sun and skade : A wkole plant perspective Funct. Plant Biul 15: 63-92.

Ginting, S.P and A. Tarigan. 2007. Nutritional quality of Stenotaphrum secundatum and Brachiari humidicola for Goats. JITV 11(4): 273-279.

Schmit, A., J. Pausch and Y. Kuzyakov. 2013. Effect of clipping and on $\mathrm{C}$ allocation and fluxes in soil under Ryegrass and Alfalfa astemared by $\mathrm{C}^{14}$ labelling.Appl. Soil Ecology 64 : 228236.

Skerman, P. J. and F. Riveros. 1990. Tropical grasses. FAO Plant Production and Protection Series No. 23, FAO, Rome 